ISSN (Online) 2710-3315

https://doi.org/10.20535/EHS.2021.233413

УДК 620.91

\title{
АЛЬТЕРНАТИВНІ ВИДИ ПАЛИВА
}

\author{
М.В. Цоколов \\ Національний технічний університет Украйни \\ "Київський політехнічний інститут імені Ігоря Сікорського" \\ пр. Перемоги, 37, Київ, 03056, Україна \\ e-mail: inactionmovie@ukr.net
}

Тривалий час основним джерелом паливно-енергетичної системи була сировина нафтового походження. В останні роки намітилася тенденція до зниження ролі нафти і нафтопродуктів у світовій економіці, що показує світова динаміка споживання первинної енергії. Якщо в 1979 році на долю нафти приходилося близько 50 \% усіх споживаних енергоносіїв, то в даний час iii частка складає лише близько 35 \%, i iï відносне споживання продовжує неухильно скорочуватися. Це пояснюється зниженням темпів росту видобутку нафти, викликаним виробленням великих родовищ, незначним введенням в експлуатацію нових родовищ, помітним скороченням інвестицій у пошуково-розвідувальні роботи. Поряд зі зменшенням світових запасів нафти спостерігається тенденція повсюдного підвищення цін на нафту і нафтові палива. Усе це створює передумови до більш широкого використання інших енергетичних ресурсів.

Приро́дні ви́ди па́лива - кам'яне вугілля, включаючи паливні продукти, одержані при збагаченні та сортуванні на підприємствах вугільної промисловості, буре вугілля (лігніт), сланці горючі, торф паливний, дрова опалювальні, деревинні відходи лісозаготівлі, деревинні відходи деревообробки, відходи сільськогосподарського виробництва (солома, качани та стебла кукурудзи, лушпиння соняшникове та рисове тощо), інші види первинного твердого палива (непридатні шпали, рудникові стійки, дерев'яна тара тощо), нафта, включаючи газовий конденсат, природний газ, до якого входить шахтний метан.

Альтернативне паливо - це рідке та газове паливо, яке $\epsilon$ альтернативою (заміною) відповідним традиційним видам палива і яке виробляється (видобувається) з нетрадиційних джерел та видів енергетичної сировини, згідно з Законом України.

Паливо визначається альтернативним, якщо воно:

- повністю виготовлене (видобуте) з нетрадиційних джерел і видів енергетичної сировини або є сумішшю альтернативного і традиційного видів палива в пропорціях, встановлених відповідно до державних стандартів;

- виготовлене (видобуте) 3 нафтових, газових, нафтогазоконденсатних родовищ непромислового значення, вичерпаних родовищ, з важких сортів нафти тощо і за своїми ознаками відрізняється від вимог до традиційного виду палива.

Нетрадиційні джерела та види енергетичної сировини - сировина рослинного походження, відходи, тверді горючі речовини, інші природні і штучні джерела та види енергетичної сировини, у тому числі нафтові, газові, газоконденсатні і нафтогазоконденсатні вичерпані, непромислового значення та техногенні родовища, важкі сорти нафти, природні бітуми, 
газонасичені води, газогідрати тощо, виробництво (видобуток) і переробка яких потребує застосування новітніх технологій і які не використовуються для виробництва (видобутку) традиційних видів палива.

До альтернативних видів рідкого палива належать:

- горючі рідини, одержані під час переробки твердих видів палива (вугілля, торфу, сланців);

- спирти та їх суміші, олії, інше рідке біологічне паливо, одержане з біологічної сировини (у тому числі з поновлюваних відходів сільського та лісового господарства, інших біологічних відходів);

- горючі рідини, одержані з промислових відходів, у тому числі газових викидів, стічних вод, виливів та інших відходів промислового виробництва;

- паливо, одержане з нафти і газового конденсату нафтових, газових та газоконденсатних родовищ непромислового значення та вичерпаних родовищ, 3 важких сортів нафти та природних бітумів, якщо це паливо не належить до традиційного виду.

До альтернативних видів газового палива належать:

- газ (метан) вугільних родовищ, а також газ, одержаний у процесі підземної газифікації та підземного спалювання вугільних пластів;

- газ, одержаний під час переробки твердого палива (кам'яне та буре вугілля, горючі сланці, торф), природних бітумів, важкої нафти;

- газ, що міститься у водоносних пластах нафтогазових басейнів 3 аномально високим пластовим тиском, в інших підземних газонасичених водах, а також у газонасичених водоймищах і болотах;

- газ, одержаний з природних газових гідратів, та підгідратний газ;

- біогаз, генераторний газ, інше газове паливо, одержане з біологічної сировини, у тому числі з біологічних відходів;

- газ, одержаний з промислових відходів (газових викидів, стічних вод промислової каналізації, вентиляційних викидів, відходів вугільних збагачувальних фабрик тощо);

- стиснений та зріджений природний газ, зріджений нафтовий газ, супутний нафтовий газ, вільний газ метан, якщо вони одержані з газових, газоконденсатних та нафтових родовищ непромислового значення та вичерпаних родовищ і не належать до традиційних видів палива.

Сфера альтернативних видів палива - сфера діяльності, пов'язана 3 виробництвом (видобутком), транспортуванням, зберіганням та споживанням альтернативних видів палива.

В залежності від виду палива (природний газ, біогаз, тверда біомаса та ін.), тобто в залежності від теплотворної здатності палива, знаючи загальну енергію палива, що необхідна для роботи установки на протязі року, можна розрахувати річну витрату палива (т/рік, $\mathrm{Hм}^{3} /$ рік). Також, якщо вже точно відомо, яке обладнання буде встановлено, можна просто ввести витрату палива з паспортних даних енергогенеруючого обладнання (кг/с, м3/c).

Українське вугілля в основному має високу собівартість. У кам'яновугільних басейнах це пов'язано з глибоким заляганням пластів та невеликою їхньою потужністю. Буре вугілля має значно меншу теплотворну здатність від кам'яного, високий вміст сірки, значну зольність. Воно придатне для брикетування, напівкоксування і газифікації. Крім того, з бурого вугілля можна одержати штучний гірський віск. В основному буре вугілля використовується на місцевих електростанціях та інших підприємствах як паливо. Основними центрами буровугільної промисловості є Ватутіне на Черкащині та Олександрія в Кіровоградській області.

Буре вугілля невигідно перевозити на далекі віддалі, тому що воно має низьку теплотворну здатність, сипучість, підвищену вологість тощо.

\footnotetext{
Handbook of the XXII International Science Conference «Ecology. Human. Society» (2021 Kyiv, Ukraine)
} 
Нафту і природний газ використовують як високоефективне паливо і цінну сировину для хімічної промисловості. На нафту в структурі видобутку палива у перерахунку на умовне паливо припадає 7,2 \%, на природний газ - 26,1\%.

Стиснутий до 200 атмосфер природний газ як моторне паливо має низку важливих переваг порівняно з бензиновим і дизельним. Серед них цілий набір чудових екологічних достоїнств - на сьогодні він є найчистішим альтернативним паливом для транспортних засобів. Достатньо сказати, що у вихлопі двигуна, котрий працює на газі, маса канцерогенів у 10, а іноді й у 100 разів менша, ніж в інших видах палива. Особливо небезпечним є дизельне - воно складне за вмістом, і вихлопні гази при його спалюванні містять понад 40 сполук. Серед них можна знайти канцерогени, мутаногени і речовини, котрі порушують функції ендокринної системи, викликають респіраторні захворювання. МО3 вже час писати свої сакраментальні попередження на кожній каністрі бензину чи дизельного палива.

Запровадження нових норм викиду в Свропі незабаром призведе до заміни існуючого парку машин екологічно чистими транспортними засобами. Після цього витрати на заправку й експлуатацію традиційних двигунів (особливо дизельних) значно зростуть. Це ще один додатковий шанс для зростання використання стиснутого газу на транспорті.

Що ще можна вважати безумовним плюсом стиснутого газу - це те, що його не можна зробити сурогатним, підробити і запропонувати в такому вигляді покупцю. У той час як на багатьох заправках бензин чи солярка є сумішшю невідомо чого.

До всього іншого, газ не змиває мастило з деталей циліндропоршневої групи, дозволяючи заощаджувати до 40 \% мастила порівняно з бензином. Газ зменшує ударні навантаження на двигун і дає можливість добре відрегульованому мотору служити в півтора разу довше. Ефективність кубометра природного газу еквівалентна літру бензину, у той час як його вартість не перевищує 50 \% від вартості бензину. Все це суттєво знижує експлуатаційні витрати.

Основними стратегічними напрямами вдосконалення структури паливно-енергетичного балансу України та вирішення інших проблем у цій сфері є:

- концентрація народногосподарських зусиль на всебічному прискоренні проведення енергозберігаючої політики. Цей найважливіший напрям вимагає, крім проведення різноманітних заходів щодо підвищення ефективності використання палива i енергії, вдосконалення самої структури народного господарства 3 пріоритетним розвитком менш енергомістких виробництв;

- вдосконалення структури балансів енергоносіїв кінцевого використання. Передбачається збільшення питомої ваги електроенергії і тепла при зниженні частки моторного палива i котельно-пічного палива безпосереднього використання. Значно збільшиться також частка споживання природних енергоресурсів як сировини, а також для інших непаливних потреб.

В балансі енергоносіїв кінцевого використання передбачається подальше збільшення частки переробних і облагороджених видів палива 3 підвищенням як якості, так i рівня переробки первинної сировини. Особливо характерним у цьому відношенні $є$ розвиток нафтопереробки із зростанням потужностей по вторинних процесах i скороченням споживання мазуту як котельно-пічного палива. Зростання витрат на видобуток нафти обумовлює економічну доцільність перевищення обсягів виробництва моторного палива та інших світлих нафтопродуктів за рахунок збільшення глибини переробки нафти замість отримання цих продуктів за рахунок додаткового видобування нафти при незмінній глибині переробки.

При формуванні територіальної структури паливно-енергетичного балансу особливого значення набуває запровадження енергозберігаючих заходів у дефіцитних на енергоресурси 
районах, а також залучення нетрадиційних джерел палива (енергії). Ці заходи створюють можливість скорочення транспортних витрат на доставку енергоресурсів з інших районів, що забезпечує суттєвий ефект, особливо для зон, які віддалені від енергетичних баз.

У промисловості, комунально-побутовій сфері та транспортних засобах як паливо використовують вугілля, природний та нафтовий попутний газ, деревину, торф, лігніт (буре вугілля), продукти нафтопереробки, біопаливо, зокрема біоетанол та біодизель, відходи сільського господарства та лісопереробки, технологічні гази металургійних та хімічних виробництв, тверді побутові відходи, шлами стічних вод, а також похідні паливні продукти генераторний газ, водовугільні суспензії, водомазутні емульсії, а також РДФ (RDF, англ., refuse derived fuel - паливо з відходів) - гранульоване паливо, вироблене з горючої складової твердих побутових відходів. Здебільшого ці види палива можуть бути альтернативними одне одному. Поширені приклади використання вугілля як палива, альтернативного природного газу, i зворотні; природного газу або іншого газового палива - замість рідкого у двигунах внутрішнього згоряння.

Застосування альтернативного палива зазвичай зумовлено економічними та ресурсними чинниками, а також екологічними міркуваннями. За низьких цін на природний газ його у великих обсягах використовували для вдування в доменні печі для зниження витрат коксу. Після зростання цін та виникнення проблем з постачанням природний газ замінили вугільним пилом. Альтернативними щодо моторних палив нафтового походження можуть бути біоетанол та дизельне пальне, виготовлені із рослинної сировини. Альтернативне паливо часто використовують як резервне, коли трапляються перерви у постачанні основного палива. Майже всі котельні установки оснащені обладнанням для використання мазуту замість природного газу на випадок припинення його постачання або за аварійного зниження тиску. У країнах Північної Свропи набуло поширення заміщення вугілля на теплових електростанціях біопаливом для зменшення обсягу шкідливих викидів.

Напрямок дослідження та пошуку альтернативних видів палива дуже актуальний у наші дні, через прямий зв'язок з наслідками використання нафти, вугілля та інших органічних та неорганічних видів палива. Ресурси Землі завжди будуть найбільшим скарбом для людства, а отже їх збереження $\epsilon$ нашим головним завданням.

\section{Література:}

1. Руденко В. Природно-ресурсний потенціал України. Київ: Либідь, 1994. 150 с.

2. Закон «Про альтернативні види палива»: за станом на 19.06. 2009 / Верховна Рада України. - http://zakon1.rada.gov.ua/cgi-bin/laws/main.cgi

3. Адаменко О., Височанський В., Льотко В. та ін. Альтернативні палива та інші нетрадиційні джерела енергії. Івано-Франківськ: Інститут менеджменту та економіки, 2001. $430 \mathrm{c}$.

4. Дудюк Д. Нетрадиційна енергетика. Львів: Магнолія 2006, 2009. 188 с.

5. Шкурідін Є. Поняття альтернативних джерел енергії // Молодий вчений. 2014. № 4 (07) (2). C. 42.

6. Голиков А. П., Олійник Я. Б., СтепаненкоА. В. Вступ до економічної і соціальної географії: Підручник. — К.: Либідь, 2002. — 320 с.

7. Трегобчук В. Ресурсно-екологічна складова національної безпеки // Економіка України. 2002. 一 № 2. - C. 4-15. 